\title{
Two New Ecdysteroids from Serratula wolffii
}

\author{
Attila Hunyadi, ${ }^{\dagger}$ Gábor Tóth, ${ }^{\ddagger}, \#$ András Simon, ${ }^{\ddagger}$ Marianna Mák, ${ }^{\S}$ Zol tán Kele, ${ }^{\perp}$ Imre Máthé, ${ }^{\dagger}$ and \\ Mária Báthori*, + \\ Department of Pharmacognosy, University of Szeged, Szeged, Eötvös utca 6, H-6720, Hungary, Institute for General and \\ Analytical Chemistry, Budapest University of Technol ogy and Economics, Budapest, Szt. Gel lért tér 4, H-1111 Hungary, \\ G. Richter Ltd., Spectroscopic Research Division, Mass Spectrometric Laboratory, Budapest 10, P.O. Box 27, H-1475 Hungary, \\ and Department of Medical Chemistry, University of Szeged, Szeged, Dóm tér 10, H-6720, Hungary
}

Received December 23, 2003

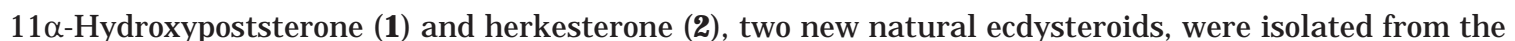
herb Serratula wolffii. The former compound is the first 11-hydroxylated $\mathrm{C}_{21}$ ecdysteroid, while the latter is a new ecdysteroid with a 7,9(11)-dien-6-one chromophore. Their structures were determined using a combination of spectroscopic techniques.

Ecdysteroids are insect hormones responsible for the regulation of molting and control of embriogenesis and vitellogenesis. Phytoecdysteroids are structurally related to the main insect hormone ecdysone. ${ }^{1}$ The diverse structural variations of phytoecdysteroids have been the basis of structure-activity experiments. These studies have proven that the ecdysteroids with a 7,9(11)-dien-6-one structural element show particularly high biological activities. ${ }^{2}$ Ecdysteroid receptors have been engineered to be gene regulation systems and are induced by phytoecdysteroids to modulate gene expression. ${ }^{3}$ Muristerone $A^{4}$ and ponasterone $A^{5}$ were found to be the two most active inducers, but efforts have been made to find additional inducers. The human gene therapy experiments have identified new ecdysteroids.

We report the isolation and structural elucidation of two new natural ecdysteroids from Serratula wolffii Andrae (Asteraceae), 11 $\alpha$-hydroxyposterone (1), and 5 $\beta, 25$-dihydroxydacryhainansterone (2). The last ecdysteroid has been given the trivial name herkesterone. Compound $\mathbf{1}$ is the first 11hydroxylated ecdysteroid of the pregnane type that shows structural similarity to muristerone A. Herkesterone (2) is an ecdysteroid 7,9(11)-dien-6-one with potential insect hormone activity.

Compounds $\mathbf{1}$ and $\mathbf{2}$ were purified by solvent-solvent distribution, precipitation with acetone, and chromatographic purification from the methanolic extract of $S$. wolffii. ${ }^{6}$ The IR spectrum of $\mathbf{1}$ showed typical absorption bands for $\mathrm{OH}$ and conjugated $\mathrm{C}=\mathrm{O}$, corresponding to common characteristics of ecdysteroids. The UV spectrum verified the presence of the 7-en-6-one chromophore of ecdysteroids. ${ }^{7}$ The molecular formula, $\mathrm{C}_{21} \mathrm{H}_{30} \mathrm{O}_{6}$, of $\mathbf{1}$ was established by the molecular ion peak, which was also consistent with the ${ }^{1} \mathrm{H}$ and ${ }^{13} \mathrm{C}$ NMR data (see Table 1 ). The ${ }^{13} \mathrm{C}$ NMR spectrum of 1 consist of 21 lines corresponding to three $\mathrm{CH}_{3}$, five $\mathrm{CH}_{2}$, seven $\mathrm{CH}$, and six nonprotonated carbon atoms. Considering the chemical shifts of the $\mathrm{CH}$ signals, three are substituted with oxygen $(\mathrm{HC}-\mathrm{O})$ and one is $=\mathrm{CH}$. Among the nonprotonated carbon atoms there are two $\mathrm{C}=\mathrm{O}$, one $\mathrm{sp}^{2}=\mathrm{C}$, and three $\mathrm{sp}^{3} \mathrm{C}$, where one is attached to oxygen. The HMBC correlations of the methyl hydrogens at $2.16 \mathrm{ppm}$ with the $\mathrm{C}=\mathrm{O}$ signal at $212.3 \mathrm{ppm}$ and with the $\mathrm{CH}$ signal at 60.0 ppm revealed the presence

\footnotetext{
* Corresponding author: Tel: 0036-62-545558. Fax: 0036-62-545704 E-mail: bathori@pharma.szote.u-szeged.hu.

† Department of Pharmacognosy, University of Szeged.

₹ Budapest University of Technology and Economics.

\# Present address: IVAX Drug Research Institut Ltd., Budapest, Berlini út 47., $\mathrm{H}$-1045, Hungary.

$\S \mathrm{G}$. Richter Ltd.

${ }^{\perp}$ Department of Medical Chemistry, University of Szeged.
}

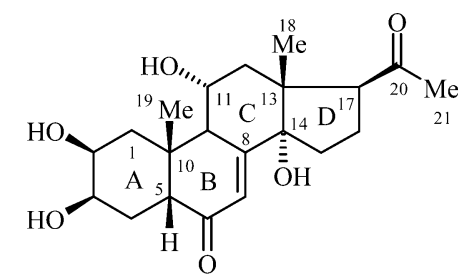

1

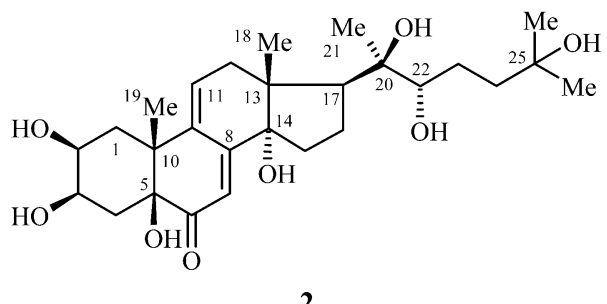

2

of an acetyl group connected to the steroid skeleton. The methyl signal at $0.61 \mathrm{ppm}$ gave HMBC cross-peaks with two quaternary carbon atoms $(48.6,84.8)$ one methylene (42.3), and one $\mathrm{CH}$ (60.0). The last correlation is consistent with the acetyl group being connected to $\mathrm{C}-17$ and the methyl at position 18. The HMBC connectivities of the methyl $\left(\delta_{\mathrm{H}}\right.$ 1.05) revealed the assignment of the C-1, C-5, C-9, and C-10 atoms. The ol efinic hydrogen showed HMBC correlations to $\mathrm{C}-5, \mathrm{C}-9$, and $\mathrm{C}-14$, placing the conjugated carbonyl at position 6 . The ${ }^{1} \mathrm{H},{ }^{1} \mathrm{H}-$ COSY correlations starting from $\mathrm{H}_{2-1}(\delta 2.60,1.38)$ revealed the connectivities of the hydrogen atoms located in the A ring, which comprises one spin system, whereas the $\mathrm{H}-9(\delta$ 3.18) correlation assigned the $\mathrm{H}-11$ and $\mathrm{H}_{2}-12$ signals (ring $\mathrm{C}$ ). The large deshielding of the $\mathrm{H}-2, \mathrm{H}-3, \mathrm{H}-11$ and $\mathrm{C}-2, \mathrm{C}-3, \mathrm{C}-11$ resonances are consistent with the $\mathrm{OH}$ substitutions. The coupling pattern of these hydrogens indicated that 2-OH and $11-\mathrm{OH}$ are located in equatorial positions and $3-\mathrm{OH}$ is axial. The ${ }^{1} \mathrm{H}$ and ${ }^{13} \mathrm{C}$ assignment of the atoms in ring $\mathrm{D}$ was supported by an HMQC-TOCSY experiment.

The NOESY correlations (Figure 1) $\mathrm{H}_{3}-19 / \mathrm{H}_{2}-1, \mathrm{H}_{3}-19 /$ $\mathrm{H}-5, \mathrm{H}-2 / \mathrm{H}-9$, and $\mathrm{H}-4 / \mathrm{H}-9$ verified the cis-type junction of the $A / B$ ring system. The NOESY cross-peaks of $\mathrm{H}_{\alpha}-12$ / $\mathrm{H}_{\alpha}-17, \mathrm{H}_{3}-18 / \mathrm{H}_{\beta}-15$, and $\mathrm{H}_{3}-18 / \mathrm{H}_{\beta}-16$ are in accordance with the trans-type connection of the C/D ring system and at the same time placed the acetyl group in the $\beta$-position.

The IR spectrum of $\mathbf{2}$ showed absorption bands for $\mathrm{OH}$, $\mathrm{C}=\mathrm{C}$, and $\mathrm{C}=\mathrm{O}$. The UV spectrum supported the presence of the 7,9(11)-dien-6-one structure. ${ }^{7}$ The mol ecular formula of $\mathbf{2}$ was established on the basis of HRESIMS. The ${ }^{1} \mathrm{H}$ and ${ }^{13} \mathrm{C}$ NMR chemical shifts of compound $\mathbf{2}$ are summarized 
Table 1. ${ }^{1} \mathrm{H}(500 \mathrm{MHz})$ and ${ }^{13} \mathrm{C}(125 \mathrm{MHz}) \mathrm{NMR}$ Spectral Data of Compounds $\mathbf{1}$ and $\mathbf{2}$ (in $\mathrm{MeOH}-\mathrm{d}_{4}$ and DMSO-d 6 in ppm)

\begin{tabular}{|c|c|c|c|c|c|c|c|}
\hline \multirow[b]{2}{*}{ position } & & \multicolumn{3}{|c|}{$\mathbf{1}\left(\mathrm{MeOH}-\mathrm{d}_{4}\right)$} & \multicolumn{3}{|c|}{$2\left(\mathrm{MeOH}-\mathrm{d}_{4}\right)$} \\
\hline & & ${ }^{13} \mathrm{C}$ & ${ }^{1} \mathrm{H}$ & mult., J $(\mathrm{Hz})$ & ${ }^{13} \mathrm{C}$ & ${ }^{1} \mathrm{H}$ & mult., J (Hz) \\
\hline \multirow[t]{2}{*}{1} & $\alpha$ & 39.2 & 2.60 & $\begin{array}{l}\text { dd; } 13.0 \text {, } \\
4.2\end{array}$ & 34.5 & 2.05 & \\
\hline & $\beta$ & & 1.38 & $\mathrm{t} ; 12.3$ & & 2.05 & \\
\hline 2 & $\alpha$ & 69.1 & 4.015 & $\begin{array}{l}\mathrm{dt} ; 11.8, \\
3.8\end{array}$ & 68.6 & 3.83 & $\begin{array}{l}\text { ddd; } 10.7 \\
5.4,3.2\end{array}$ \\
\hline 3 & $\alpha$ & 68.7 & 3.96 & $\mathrm{q} ; 2.9$ & 70.3 & 3.88 & $q ; 3.0$ \\
\hline \multirow[t]{2}{*}{4} & $\alpha$ & 33.5 & 1.775 & $\begin{array}{l}\text { td; } 13.6, \\
2.4\end{array}$ & 39.2 & 1.92 & $\begin{array}{l}\text { dd; } 14.5 \text {, } \\
2.8\end{array}$ \\
\hline & $\beta$ & & 1.70 & & & 1.77 & dd; ?, 3.4 \\
\hline 5 & $\beta$ & 53.0 & 2.345 & $\begin{array}{l}\text { dd; } 13.1 \text {, } \\
4.1\end{array}$ & 80.5 & & \\
\hline 6 & & 206.6 & & & $203.1^{a}$ & & \\
\hline 7 & & 123.3 & 5.807 & $\mathrm{~d} ; 2.7$ & 117.9 & 5.83 & $\mathrm{t} ; 1.2$ \\
\hline 8 & & 164.4 & & & 156.5 & & \\
\hline 9 & $\alpha$ & 43.1 & 3.18 & $\begin{array}{l}\text { dd; } 8.9 \\
2.7\end{array}$ & 137.9 & & \\
\hline 10 & & 40.1 & & & 46.4 & & \\
\hline 11 & $\beta$ & 69.4 & 4.08 & $\begin{array}{l}\text { ddd; } 10.8 \text {, } \\
8.9,5.8\end{array}$ & 134.3 & 6.34 & $\mathrm{dt} ; 6.7,2.0$ \\
\hline \multirow[t]{2}{*}{12} & $\alpha$ & 42.3 & 2.406 & $\mathrm{t} ; 11.4$ & 39.2 & 2.726 & $\begin{array}{l}\mathrm{dd} ; 18.0, \\
1.8\end{array}$ \\
\hline & $\beta$ & & 2.08 & $\begin{array}{l}\text { dd; } 12.0 \text {, } \\
5.8\end{array}$ & & 2.436 & $\begin{array}{l}\text { dd; } 18.2 \text {, } \\
6.7\end{array}$ \\
\hline 13 & & $\begin{array}{l}48.6 \\
84.8\end{array}$ & & & 48.0 & & \\
\hline \multirow[b]{2}{*}{15} & $\alpha$ & $\begin{array}{l}84.8 \\
323\end{array}$ & & & 84.5 & & \\
\hline & $\beta$ & 32.3 & $\begin{array}{l}1.68 \\
2.00\end{array}$ & & 31.5 & $\begin{array}{l}1.80 \\
1.98\end{array}$ & \\
\hline 16 & $\alpha$ & 22.4 & $\begin{array}{l}1.90 \\
2.245\end{array}$ & & 21.8 & $\begin{array}{l}1.79 \\
1.99\end{array}$ & \\
\hline 17 & $\alpha$ & 60.0 & 3.36 & $\begin{array}{l}\text { dd; } 9.4 \text {, } \\
8.1\end{array}$ & 50.7 & 2.49 & $\mathrm{t} ; 9.0$ \\
\hline 18 & $\beta$ & 18.4 & 0.61 & $\mathrm{~s}$ & 18.2 & 0.90 & $\mathrm{~s}$ \\
\hline 19 & $\beta$ & 24.8 & 1.05 & $\mathrm{~s}$ & 26.5 & 1.05 & $\mathrm{~s}$ \\
\hline 20 & & 212.3 & & & 77.8 & & \\
\hline 21 & & 31.6 & 2.16 & $\mathrm{~s}$ & 20.9 & 1.208 & $\mathrm{~s}$ \\
\hline 22 & & & & & 78.6 & 3.35 & $\begin{array}{l}\text { dd; } 10.3 \text {, } \\
1.8\end{array}$ \\
\hline \multirow[t]{2}{*}{23} & $\alpha$ & & & & 27.5 & 1.30 & \\
\hline & $\beta$ & & & & & 1.68 & \\
\hline \multirow[t]{2}{*}{24} & $\alpha$ & & & & 42.5 & 1.44 & $\begin{array}{l}\text { ddd; } 13.3 \text {, } \\
11.6,4.2\end{array}$ \\
\hline & $\beta$ & & & & & 1.81 & \\
\hline 25 & & & & & 71.4 & & \\
\hline 26 & & & & & 29.1 & 1.19 & $\mathrm{~s}$ \\
\hline 27 & & & & & 29.9 & 1.206 & $\mathrm{~s}$ \\
\hline
\end{tabular}

a Very weak intensity in the ${ }^{13} \mathrm{C}$ spectrum.

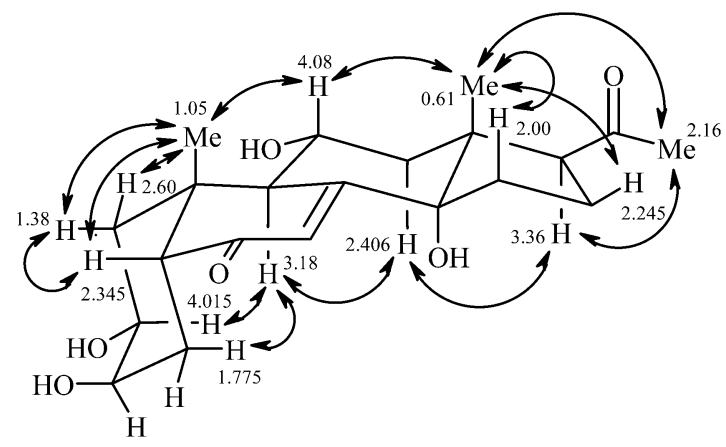

Figure 1. Stereostructure of compound $\mathbf{1}$. The double arrows indicate the observed characteristic NOE correlations.

in Table 1. For the structure elucidation of compound $\mathbf{2}$ we utilized the same type of NMR measurements as described above. Here we discuss only the essential features of the structure elucidation. The presence of an $\alpha, \beta, \gamma, \delta$ conjugated ketone was established on the basis of HMBC correlation of $\mathrm{H}-7$ (5.83) with the quaternary $=\mathrm{C}$ signal at $\delta 137.9$ and further supported by the $\mathrm{H}-11 / \mathrm{H}_{2}-12$ correlations observed in the ${ }^{1} \mathrm{H},{ }^{1} \mathrm{H}-$ COSY spectrum. The
HMBC cross-peaks of $\mathrm{H}_{3}-19(\delta$ 1.05) and $\mathrm{H}-7$ with the signal at $\delta 80.5$ proved the presence of an $\mathrm{OH}$ substituent at $\mathrm{C}-5$. The chain attached to $\mathrm{C}-17$ is common in several ecdysteroids, and the observed chemical shifts for compound $\mathbf{2}$ are in accord with literature data. ${ }^{7} \mathrm{H}-2$ is axial, as evident from its coupling constant of $10.7 \mathrm{~Hz}$. The detected NOESY correlation between $\mathrm{H}-2$ and $\mathrm{H}-11$ is unique and provides straightforward evidence for the cistype $A / B$ ring junction (Figure 2). It is worth mentioning that the semiempirical calculation (HyperChem Release 7.0) showed 2.8 and $4.3 \AA$ internuclear $\mathrm{H}-2$ and $\mathrm{H}-11$ distances for cis- and trans-type ring junctions, respectively. To gather further evidence for the structure and the cis-type A/B ring junction, a ROESY spectrum was measured in DMSO- $d_{6}$. The expected correlations of the $5-\mathrm{OH}$ proton were not observed due to exchange; only the 22$\mathrm{OH}$ gave COSY correlation.

Compound $\mathbf{1}$ is the first $\mathrm{C}_{21}$ ecdysteroid with an important corticoid hydroxylation. ${ }^{8}$ On the basis of the structureactivity studies the presence of the 7,9(11)-dien-6-one chromophore and $5 \beta$-hydroxyl and the absence of a 25 hydroxyl group usually increase the insect hormone activity 


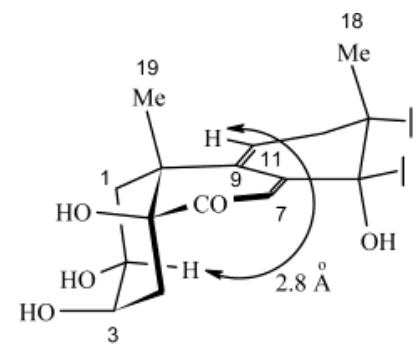

cis-type $\mathrm{A} / \mathrm{B}$ ring junction

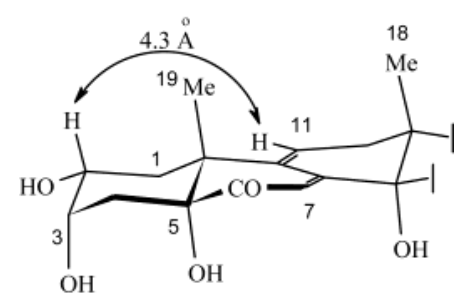

trans-type $\mathrm{A} / \mathrm{B}$ ring junction

Figure 2. A/B ring junction structures of $\mathbf{2}$ and its $5 \alpha-\mathrm{OH}$ isomer with the calculated (HyperChem Release 7.0) distances between $\mathrm{H}-11$ and $\mathrm{H}_{\mathrm{ax}}-2$ (see double arrow).

of ecdysteroids. ${ }^{2}$ Compound 2, with a 7,9(11)-dien-6-one chromophore and $5 \beta$ - and 25-hydroxylations, represents a new lead compound to study the common effects of these substitutions on activity.

\section{Experimental Section}

General Experimental Procedures. Melting points were measured with a Boetius apparatus (Dresden, Germany). Optical rotations were measured with a Perkin-Elmer 341 polarimeter. The UV spectra were recorded in $\mathrm{MeOH}$ using a Shimadzu UV 2101 PC spectrophotometer. FT-IR spectra $(\mathrm{KBr})$ were recorded using a Perkin-EImer Paragon $1000 \mathrm{PC}$ FT-IR spectrophotometer. NMR spectra were recorded in $\mathrm{MeOH}-\mathrm{d}_{4}$ and in DMSO- $\mathrm{d}_{6}$ in a Shigemi sample tube ${ }^{9}$ at room temperature using a Bruker Avance DRX-500 spectrometer. Chemical shifts are given on the $\delta$-scale and were referenced to the solvents $\left(\mathrm{MeOH}-\mathrm{d}_{4}: \delta_{\mathrm{C}}=49.1\right.$ and $\delta_{\mathrm{H}}=3.31$; DMSO$\mathrm{d}_{6}: \delta_{\mathrm{C}}=39.5$ and $\left.\delta_{\mathrm{H}}=2.51\right)$. In the $1 \mathrm{D}$ measurements $\left({ }^{1} \mathrm{H}\right.$, ${ }^{13} \mathrm{C}$, DEPT-135) $64 \mathrm{~K}$ data points were used for the FID. The pulse programs of the 2D experiments [gs-COSY, gs-HMQC, HMQC-TOCSY (mixing time $=100 \mathrm{~ms}$ ), gs-HMBC, NOESY (mixing time $=500 \mathrm{~ms}$ ), ROESY (mixing time $=300 \mathrm{~ms}$ )] were taken from the Bruker software library, and the other parameters (pulse lengths and levels, delays, etc.) were in agreement with the parameters given in our previous work. ${ }^{10}$ HRESIMS and FABMS were recorded on a Finnigan MAT 95SQ (Finnigan MAT, Bremen, Germany) hybrid tandem mass spectrometer. The stationary phase for the low-pressure reversed-phase column chromatography was Kovasil C18 (0.06-0.02 $\mu \mathrm{m}$, Chemie Uetikon, Uetikon, Switzerland), and a Zorbax-SIL column (5 $\mu \mathrm{m}$, DuPont, Paris, France) was used for HPLC.

Plant Material. The aerial parts of Serratula wolffii were collected in J uly 2001 from Herencsény, Hungary. A voucher specimen (collection number S94) was deposited at the Department of Pharmacognosy, University of Szeged, Hungary.

Extraction and Isolation. The dried herb $(2 \mathrm{~kg})$ was extracted with $\mathrm{MeOH}$, purified with fractionated precipitation and solvent-solvent distribution, ${ }^{6}$ and subjected to column chromatography on silica gel. Fractions eluted before 20hydroxyecdysone $\left[\mathrm{CH}_{2} \mathrm{Cl}_{2}-\mathrm{MeOH}, 8: 2(4.3 \mathrm{~g})\right]$ were separated by a combination of polyamide $\left[\mathrm{H}_{2} \mathrm{O}, \mathrm{H}_{2} \mathrm{O}-\mathrm{MeOH}, 75: 25\right.$ (3.5 g)], alumina, and silica $\left[\mathrm{CH}_{2} \mathrm{Cl}_{2}-\mathrm{MeOH}, 9: 1(0.26 \mathrm{~g})\right]$ and lowpressure reversed-phase column chromatography. Fractions eluted with $\mathrm{MeOH}-\mathrm{H}_{2} \mathrm{O}$ (40:60) from the reversed-phase col umn $(0.13 \mathrm{~g})$ gave $\mathbf{1}(2.2 \mathrm{mg})$. The 20-hydroxyecdysonecontaining fractions eluted by $\mathrm{CH}_{2} \mathrm{Cl}_{2}-\mathrm{MeOH}(8: 2)(13.6 \mathrm{~g})$ from the first silica column were purified by column chromatography on alumina. Ecdysteroids eluted after 20-hydroxyecdysone with $\mathrm{CH}_{2} \mathrm{Cl}_{2}-\mathrm{MeOH}(9: 1)(0.67 \mathrm{~g})$ were subjected to reversed-phase column chromatography. Fractions eluted by $\mathrm{MeOH}-\mathrm{H}_{2} \mathrm{O}$ (45:55) (3 mg) were purified by normal-phase $\mathrm{HPLC}\left[\mathrm{CH}_{2} \mathrm{Cl}_{2}-\mathrm{i}-\mathrm{PrOH}-\mathrm{H}_{2} \mathrm{O}\right.$ (125:40:3)] to give 2 (0.7 mg).

11 $\alpha$-Hydroxyposterone (1): colorless crystals, mp 174$176^{\circ} \mathrm{C} ;[\alpha]^{28} \mathrm{D}+12^{\circ}$ (c 0.1, MeOH); UV (MeOH) $\lambda_{\max }(\log \epsilon) 240$ (4.116) $\mathrm{nm}$; IR $(\mathrm{KBr})_{\max } 3320,1718,1653 \mathrm{~cm}^{-1} ;{ }^{1} \mathrm{H}$ and ${ }^{13} \mathrm{C}$ NMR (see Table 1); FABMS m/z $379[\mathrm{M}+\mathrm{H}]^{+}(100), 361[\mathrm{M}$ $\left.+\mathrm{H}-\mathrm{H}_{2} \mathrm{O}\right]^{+}(88), 343\left[\mathrm{M}+\mathrm{H}-2 \mathrm{H}_{2} \mathrm{O}\right]^{+}(40), 325[\mathrm{M}+\mathrm{H}-$ $\left.3 \mathrm{H}_{2} \mathrm{O}\right]^{+}$(10), 299 (11), 282 (32), 277 (13), 249 (80), 231 (20); HRESIMS m/z 378.2045 (calcd for $\mathrm{C}_{21} \mathrm{H}_{30} \mathrm{O}_{6}, 378.2042$ ).

Herkesterone (2): col orless crystals, $\mathrm{mp} 218^{\circ} \mathrm{C}(\mathrm{dec}) ;[\alpha]^{28} \mathrm{D}$ $+59^{\circ}$ (c 0.1, DMSO); UV (MeOH) $\lambda_{\max }(\log \epsilon) 296$ (4.02) nm; IR $(\mathrm{KBr})_{\max } 3560-3200,1650,1602 \mathrm{~cm}^{-1} ;{ }^{1} \mathrm{H}$ and ${ }^{13} \mathrm{C} N M R$ $\left(\mathrm{MeOH}-\mathrm{d}_{4}\right)$, see Table $1 ;{ }^{1} \mathrm{H}$ NMR (DMSO- $\left.\mathrm{d}_{6}, 500 \mathrm{MHz}\right) \delta 5.65$ $(1 \mathrm{H}, \mathrm{s}, \mathrm{H}-7), 6.18(1 \mathrm{H}, \mathrm{s} \mathrm{br} ; \mathrm{H}-11 \beta), 2.59(1 \mathrm{H}, \mathrm{d} ; \mathrm{J}=17.8 \mathrm{~Hz}$, $\mathrm{H}-12 \alpha), 2.29(1 \mathrm{H}, \mathrm{dd} ; \mathrm{J}=17.8,6.6 \mathrm{~Hz}, \mathrm{H}-12 \beta), 1.60 *(1 \mathrm{H}$, $\mathrm{H}-16 \alpha), 1.89 *(1 \mathrm{H}, \mathrm{H}-16 \beta)$ (*assignment can be interchanged), $2.36(1 \mathrm{H}, \mathrm{t} ; \mathrm{J}=9.3, \mathrm{H}-17 \alpha), 0.77\left(3 \mathrm{H}, \mathrm{s}, \mathrm{CH}_{3}-18 \beta\right), 0.96(3 \mathrm{H}$, $\mathrm{s}$ b; $\left.\mathrm{CH}_{3}-19 \beta\right), 1.075\left(3 \mathrm{H}, \mathrm{s}, \mathrm{CH}_{3}-21\right), 3.13(1 \mathrm{H}, \mathrm{d}$; J $=10.2$, $\mathrm{H}-22), 4.42(1 \mathrm{OH}, \mathrm{OH}-22) \mathrm{COSY}$ to $\mathrm{H}-22,1.13(1 \mathrm{H}, \mathrm{H}-23 \mathrm{a})$, 1.49 (1H, H-23b), 1.27 (1H, td; J = 12.0, 4.3, H-24a), $1.65(1 \mathrm{H}$, $\mathrm{H}-24 \mathrm{~b}), 1.06\left(3 \mathrm{H}, \mathrm{S}, \mathrm{CH}_{3}-26\right), 1.09\left(3 \mathrm{H}, \mathrm{S}, \mathrm{CH}_{3}-27\right) ;{ }^{13} \mathrm{C} \mathrm{NMR}$ (DMSO-d, $125 \mathrm{MHz}) \delta 78.4$ (C-5), 116.5 (C-7), 136.3 (C-9), 131.7 (C-11), 37.5 (C-12), 46.3 (C-13), 82.0 (C-14), 20.4 (C-16), 48.7 (C-17), 17.3 (C-18), 25.8 (C-19), 75.5 (C-20), 20.7 (C-21), 76.3 (C-22), 26.1 (C-23), 41.4 (C-24), 68.7 (C-25), 29.0 (C-26), 30.0 (C-27); ESIMS m/z $495[\mathrm{M}+\mathrm{H}]^{+}(9), 477\left[\mathrm{M}+\mathrm{H}-\mathrm{H}_{2} \mathrm{O}\right]^{+}$ (10), 459 (23), 443 (26), 440 (11), 422 (8), 407 (49), 394 (17), 378 (9), 361 (26), 359 (10), 323 (18), 300 (100), 199 (11); HRESIMS m/z 494.2885 (calcd for $\mathrm{C}_{27} \mathrm{H}_{42} \mathrm{O}_{8}, 494.2880$ ).

Acknowledgment. This project was supported by the Hungarian National Research Fund (OTKA D32830, T032618, T035054, and T046127). A.S. is grateful for Bolyai, Békésy, and Varga/Rohr Fellowships.

\section{References and Notes}

(1) Dinan, L.; Harmatha, J .; Lafont, R. J . Chromatogr. A 2001, 935, 105123.

(2) Bourne, C. B.; Whiting, P.; Dhadialla, T. S.; Hormann, R. E.; Girault, J. G.; Harmatha, J .; Lafont, R.; Dinan, L. J . Insect Sci. 2002, 2:11, $1-11$.

(3) Lafont, R.; Dinan, L. J ournal of Insect Science 2003, 3:7, 1-30.

(4) Saez, E.; Nelson, M. C.; Eshelman, B.; Banayo, E.; Koder, A.; Cho, G. J .; Evans, R. M. Proc. Natl. Acad. Sci. U.S.A. 2000, 97, 1451214517.

(5) Christopherson, K. S.; Mark, M. R.; Bajaj, V.; Godowski, P. J . Proc Natl. Acad. Sci. U.S.A. 1992, 89, 6314-6318.

(6) Báthori, M.; Kalász, H.; Pongrácz, Z.; Máthé, I.; Kálmán, A.; Argai G. Biomed. Chromatogr. 2002, 16, 373-378.

(7) www.ecdybase.org

(8) Slama, K.; Lafont, R. Eur. J . Entomol. 1995, 92, 355-377.

(9) www.sigmaaldrich.com, Product No. Z 529214 and Z 529249

(10) Tóth, G.; Simon, A.; Elgamal, M. H. A.; Soliman, H. S. M.; Elmunajied, D. T.; Horváth, Gy.; Duddeck, H. Magn. Reson. Chem. 1998, 36, $376-380$.

NP030544P 